\title{
Microsatellite markers for the Arctic copepod Calanus glacialis and cross-amplification with $C$. finmarchicus
}

\author{
Agata Weydmann • Nelson C. Coelho • \\ Ana A. Ramos • Ester A. Serrão • Gareth A. Pearson
}

Received: 18 June 2014/ Accepted: 7 July 2014/Published online: 31 July 2014

(c) The Author(s) 2014. This article is published with open access at Springerlink.com

\begin{abstract}
Calanus glacialis is a major component of Arctic zooplankton and a keystone species in Arctic marine ecosystems. Due to the observed climate warming, its numbers are being reduced to the advantage of a sibling Atlantic species Calanus finmarchicus. We developed and characterized the first set of microsatellite markers in this species to investigate its population genetic structure and dispersal capabilities. Nine polymorphic loci displayed an average of 7.3 alleles (range between 2 and 13) and the levels of expected heterozygosity ranged from 0.039 to 0.806 . These provide a valuable tool to understand present connectivity patterns across Arctic regions, look for signatures of past climate effects and predict the response to future climate-driven environmental changes. Additionally, due to the cross-amplification with $C$. finmarchicus, the markers can be used to discriminate between these sibling species.
\end{abstract}

Keywords Calanus $\cdot$ Zooplankton $\cdot$ Microsatellites · Population genetics $\cdot$ Genetic diversity

Electronic supplementary material The online version of this article (doi:10.1007/s12686-014-0269-6) contains supplementary material, which is available to authorized users.

\footnotetext{
A. Weydmann $(\bowtie)$

Marine Ecology Department, Institute of Oceanology, Polish Academy of Sciences, Powstancow Warszawy 55, 81-712 Sopot, Poland

e-mail: agataw@iopan.gda.pl

N. C. Coelho - A. A. Ramos - E. A. Serrão - G. A. Pearson CCMAR, CIMAR-Laboratório Associado, University of Algarve, Campus de Gambelas, 8005-139 Faro, Portugal

N. C. Coelho

Department of Biological Sciences, University of WisconsinMilwaukee, Milwaukee, WI 53201-0413, USA
}

Calanus glacialis occurs in seas bordering the Arctic Ocean, where it is one of the key zooplankton components. It plays an important role in marine ecosystems, linking ice algae and phytoplankton with other zooplankton species, polar cod and seabirds (Falk-Petersen et al. 2007). Recent environmental changes in the Arctic, such as increasing water temperature and loss of sea ice, affect this species. Its presence and biomass decreases in the Nordic Seas above a critical threshold around $6{ }^{\circ} \mathrm{C}$ (Carstensen et al. 2012). At the same time, increasing numbers of its sibling Calanus finmarchicus are observed (Weydmann et al. 2014). The reproduction of these copepods, which need energy from the ice-algal bloom to maximize egg production, may also be affected by the warming and loss of sea-ice (Søreide et al. 2010).

The purpose of this study was to describe novel, variable genetic markers to aid in studies of $C$. glacialis. These markers are needed for population genetic studies and for species diagnostics, as a contribution to understand the future of Calanus in a warmer Arctic scenario. We also tested the potential for cross-amplification of all the developed microsatellites on the Atlantic C. finmarchicus.

Total RNA was isolated using the RNeasy Kit (Qiagen) from eight $C$. glacialis copepodites collected from the Barents Sea in June 2009. cDNA was synthesized with the SMARTer ${ }^{\mathrm{TM}}$ PCR cDNA synthesis kit (Clontech) and approximately $4 \mu \mathrm{g}$ of normalized cDNA were sequenced using 454-pyrosequencing technology (Biocant, Cantanhede, Portugal). Cleaned reads were assembled using MIRA v3.0.3. Putative simple sequence repeats (SSRs) were identified using MSATCOMMANDER v0.8.2. Twentyfive primer pairs were designed with Primer3 and further genotyping was conducted on $25 \mathrm{C}$. glacialis and $24 \mathrm{C}$. finmarchicus individuals collected in April 2008 from Rijpfjorden (Svalbard), using fluorescent-dye labeled 


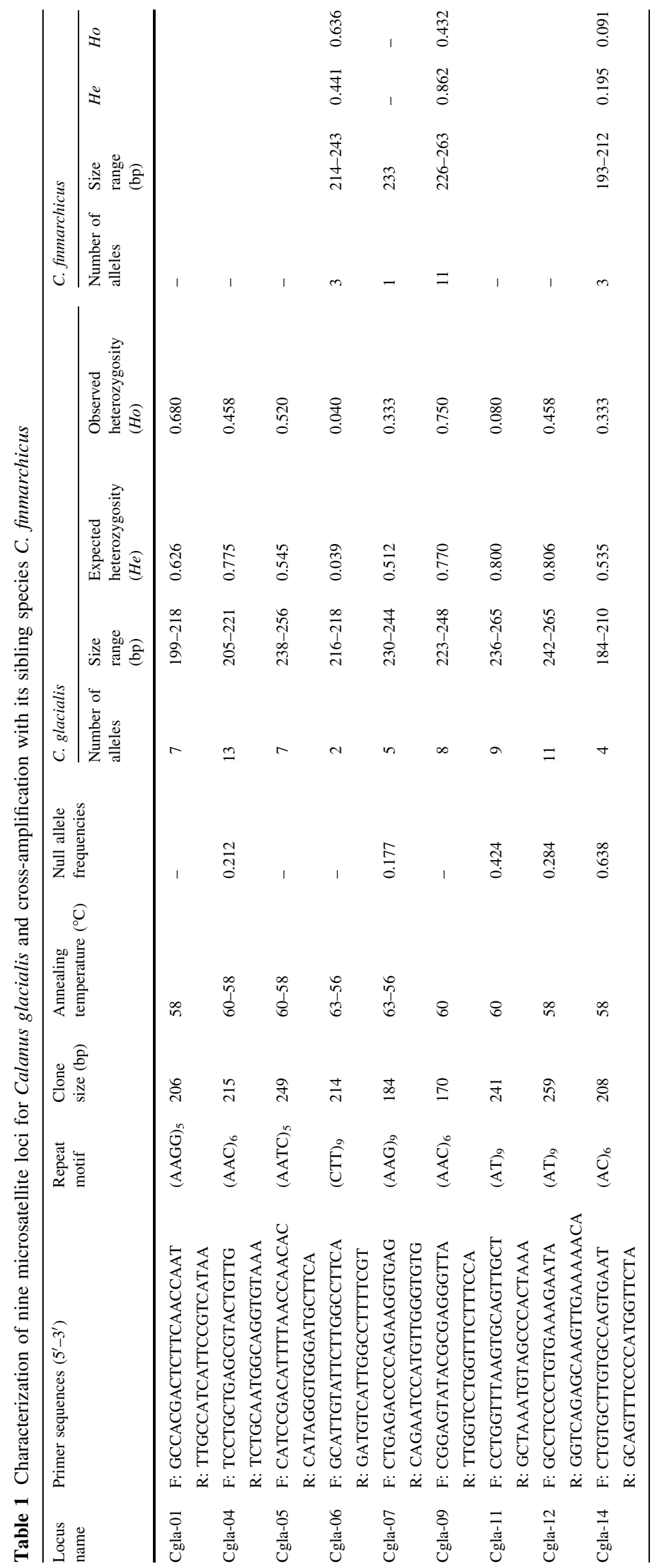


primers. PCR reactions $(15 \mu \mathrm{l})$ contained $\pm 20 \mathrm{ng}$ of DNA, $0.1 \mu \mathrm{M}$ of each primer (Table 1 ), $0.8 \mathrm{mM}$ of dNTPs, $2.0 \mathrm{mM}$ of $\mathrm{MgCl}_{2}, 3.0 \mu \mathrm{l}$ of $5 \times$ PCR Buffer and $0.4 \mathrm{U}$ of GoTaq Polymerase (Promega Madison, WI). Cycle conditions were as follows: $95^{\circ} \mathrm{C}$ for $5 \mathrm{~min}, 35$ cycles $\left(95^{\circ} \mathrm{C}\right.$, $30 \mathrm{~s}$; annealing temperature-Table $1,30 \mathrm{~s} ; 72{ }^{\circ} \mathrm{C}, 45 \mathrm{~s}$ ), $72{ }^{\circ} \mathrm{C}$, $20 \mathrm{~min}$ (GeneAmp 9700 thermocycler, Applied Biosystems). Fragments were sized using an ABI PRISM 3130xl DNA analyzer (Applied Biosystems) and allele sizes were scored with STRAND. GENETIX 4.0.5 was used to check allelic richness and expected and observed heterozygosities. Linkage disequilibrium was tested by GENEPOP v.4.1.4 and the frequency of null alleles was estimated using MICRO-CHECKER.

A total of 9 loci were selected for further studies (Table 1). Allelic richness ranged from 2 to 13 (mean $=7.3$ ) and expected heterozygosity from 0.039 to 0.806. No significant disequilibrium was found between any pair of primers. High frequency of null alleles was likely at two of these loci (Cgla-11, Cgla-14; Table 1).

The test of cross-amplification with $C$. finmarchicus resulted in four amplified loci, three of which produced polymorphic products (Table 1). These loci showed some species-specific alleles and $C$. finmarchicus did not amplify for the remaining five of our nine microsatellite loci. Therefore, they are useful to discriminate between $C$. glacialis and C. finmarchicus, which are often difficult to identify based only on their morphological features. Additionally, the polymorphic locus Cgla-09, with 11 alleles and gene diversity of 0.86 , may provide a useful marker for population genetic studies in C. finmarchicus, complementing the markers described in previous reports (Provan et al. 2007).
Acknowledgments This research was supported by Grant No. 2011/03/B/NZ8/02876 from the National Science Centre, Poland; FCT (PTDC/MAR/72630/2006), Portugal; and EU FP7 Project ATP (No. 226248). Agata Weydmann visited CCMAR thanks to the support of the European Community (ASSEMBLE-MARINE Grant agreement No. 227799).

Open Access This article is distributed under the terms of the Creative Commons Attribution License which permits any use, distribution, and reproduction in any medium, provided the original author(s) and the source are credited.

\section{References}

Carstensen J, Weydmann A, Olszewska A, Kwaśniewski S (2012) Effects of environmental conditions on the biomass of Calanus spp. in the Nordic Seas. J Plankton Res 34:951-966

Falk-Petersen S, Timofeev S, Pavlov V, Sargent JR (2007) Climate variability and possible effects on Arctic food chains: the role of Calanus. In: Ørbæk JB, Tombre T, Kallenborn R, Hegseth E, Falk-Petersen S, Hoel AH (eds) Arctic-alpine ecosystems and people in a changing environment. Springer, Berlin, pp 147-166

Provan J, Beatty GE, Maggs CA, Savidge G (2007) Expressed sequence tag-derived microsatellites for the cool-water marine copepod Calanus finmarchicus. Mol Ecol Notes 7:1369-1371

Søreide JE, Leu E, Berge J, Graeve M, Falk-Petersen S (2010) Timing of blooms, algal food quality and Calanus glacialis reproduction and growth in a changing Arctic. Glob Change Biol 16:3154-3163

Weydmann A, Carstensen J, Goszczko I, Dmoch K, Olszewska A, Kwasniewski S (2014) Shift towards the dominance of boreal species in the Arctic: inter-annual and spatial zooplankton variability in the West Spitsbergen Current. Mar Ecol Prog Ser 501:41-52 